\title{
How Durable is Root Knot Nematode Resistance in Tomato?
}

\author{
M. Harunur Rashid ${ }^{1,2 *}$, M. H. Al-Mamun ${ }^{2}$, M. Nazim Uddin ${ }^{2}$ \\ ${ }^{1}$ Department of Plant Science, University of Manitoba, Winnipeg, MB, R3T 2N2, Canada (present address) \\ ${ }^{2}$ Olericulture Division, Horticulture Research Centre, BARI, Gazipur-1701, Bangladesh
}

\begin{abstract}
Among the plant parasitic nematodes, root knot nematode (RKN) is the most devastating in tomato growing regions. Controlling RKN mostly relies on nematicides. Since chemical application is limited due to adverse environmental effect, alternative approaches are required. Although there are some alternatives, but resistance cultivars are getting popularity in the farmer's field because of simplicity, cost-effective and environment safety. Genes conferring resistance to RKN have already been identified followed by the introgression into elite cultivars. Currently, natural resistance genes $(R$ genes $)$ are used in conventional breeding programmes. Simultaneously, molecular research is going on to characterize and map the linked markers for the detected resistant phenotypes. Currently, it is a prominent threat to maintain the durability of existing $R$ genes. However, durability of host resistance govern by co-evolution of resistance genes from plants and (a)virulence genes from nematodes. So, understanding the mechanisms underlying co-evolution is essential for the durability of $R$ genes. Here we review the existing potential natural resistance in tomato against RKN, currently used resistance mechanisms between RKN and tomato, influential factors of durability of natural resistance genes and opportunity to get more durable resistance in tomato.
\end{abstract}

Keywords Root-knot nematode, Natural resistance, $M i$-gene, $R$-genes durability, Tomato

\section{INTRODUCTION}

\section{Background information}

Root-knot nematodes (RKN) are the members of the genus Meloidogyne, including Meloidogyne incognita, $M$. javanica, M. hapla, and M. arenaria. These species are considered as phytopathogenic obligate sedentary endoparasites (Kiewnick et al. 2009), can infect roots of many plant species. These are the economically important species in tomato that decline both yield and quality of the tomato fruits, but the damage caused by the RKN species has not been precisely determined. Disease symptoms and yield losses are often associated with the pre-plant invasion levels and the environmental stresses imposed to the plant throughout the growing season. The disease caused by the RKN is characterized by the occurrence of galls or root-knots in infested plants. Disease symptoms consist of meager fruit yield, wilting, stunted growth and subsequently susceptibility to other pathogens. On the other hand, it has always been challenging to manage plantparasitic nematodes in an intensive agricultural system. Over 50 years, methyl bromide the toxic fumigant has been used as the most successful control strategy, but the application of fumigant and nematicides has numerous disadvantages along with the threats of environmental pollution and human health. Moreover, it has no effective suppression of nematode populations for a long-term. Despite the fact that high input-intensive production systems including chemical control imposes huge financial load to the farmers that may not be cost-effective (Sorribas et al. 2005).

Received May 31, 2017; Revised June 17, 2017; Accepted June 17, 2017; Published September 1, 2017

*Corresponding author M. Harunur Rashid, rashidhrc@gmail.com, Tel: +1-431-999-3623, Fax: +1-204-474-7528 


\section{Justification of topic}

The highly effective fumigant and nematicides have been banned in many countries due to concerning atmospheric ozone depletion and human health (Sikora and Fernandez 2005), resulted in diminishing role of nematicides in crop protection. But biological control agent like arbuscular mycorrhizal fungi (AMF) may offer an alternative to pesticide use that is more sustainable and environment friendly (Dong and Zhang 2006). Vos et al. (2012) reported that nematode penetration was significantly reduced in tomato roots while treated by the AMF. It could be affected nematode motility at least partially with mycorrhizal root exudates. Although other strategies exist to control the RKN, including crop rotation, cultural manipulations (Goswami et al. 2008), organic amendments (Wachira et al. 2009), use of neem formulation (Javed et al. 2008) and resistance rootstock (Jacquet et al. 2005) but breeding for resistant cultivars have been popular since 1948, because of the simplicity of transferring single dominant $R$ gene into elite cultivars. Now-a-days, it is a great challenge for breeders to bred crops against available isolates of RKN, which are evolved frequently. Assortment of Meloidogyne species those are infecting tomatoes worldwide, is a great threat of cultivars that showing resistance mediated by a single dominant $R$ gene. Djianaporalino et al. (2011) reported the reproduction of $M$. incognita in a tomato variety that carry the corresponding $R$ gene, supporting the shifting of avirulence to virulence. In fact new virulent strains have been reported in many regions of the world where tomato is growing in a large acreage (Tzortzakakis et al. 2005; Verdejo-Lucas et al. 2009; Devran and Söğüt 2010), indicating significant reduction of the durability of $R$ genes in tomato production. Tomato is a top crop species in which numerous molecular markers and maps have been developed by the last few years (Foolad 2007). Currently, tomato genome sequencing data is also available. So, marker assisted breeding could be a faster approach to identify new resistance sources, which will accelerate breeding program to develop new cultivars resistance to RKN. However, management of single dominant $R$ gene in an appropriate manner would be a crucial issue to enhance their durability.
The overall objective of the review is to understand the durability of currently used $R$ genes in controlling RKN in tomato production. Then we have been analysed the information from the answers of the sub-questions, (i) what are the existing resistance mechanism between RKN and tomato plant? (ii) What are the limiting factors for the durability of natural resistance? How do get more durable resistance to RKN in tomato?

\section{COMPATIBLE INTERACTION BETWEEN PLANT AND RKN}

\section{Establishment of nematode-induced feeding site (NFS)}

$\mathrm{RKN}$ is an obligate parasite spending a part of life cycle into plant roots. The most infective second stage juveniles (J2) of RKN mechanically enter root cortex and move towards the root tips followed by intercellular migration to a site near the vascular tissue (Fig. 1A). The migration is complemented by the esophageal cell wall degrading enzymes, a secretion of endoparasitic nematode during the invasion of root tissue. A successful parasitic interaction usually accelerates the modification of root parenchyma cells. This modification characterised by the highly specialized large, metabolically active and multinucleate feeding cells known as giant cells (GCs) (Fig. 1B). Huang et al. (2006) reported that a peptide 13-amino-acid secreted by the plant-parasitic nematode functions here as a signalling molecule to induce root proliferation. Authors speculated that the putative ligand-receptor pair may have a role in giant cell induction during compatible interaction between RKN and plant. In model plant Arabidopsis, PLL18 and PLL19 pectate lyse-like genes found to be expressed during giant cells induction by the RKN Meloidogyne incognita reported by Wieczorek et al. (2014). However, a combination of physiological (where a developmental switch is aggravated) and biological changes lead to form GCs (Bleve-Zacheo and Melillo 1997). A single J2 induces 5 to 12 metabolically active GCs which become nematode feeding site (NFS) during their parasitic phase. Once the NFS is instigated, J2s turn into sedentary and progress towards third $(\mathrm{J} 3 \mathrm{~s})$ and fourth $(\mathrm{J} 4 \mathrm{~s})$ stage juvenile, and finally develop adult males or females. 


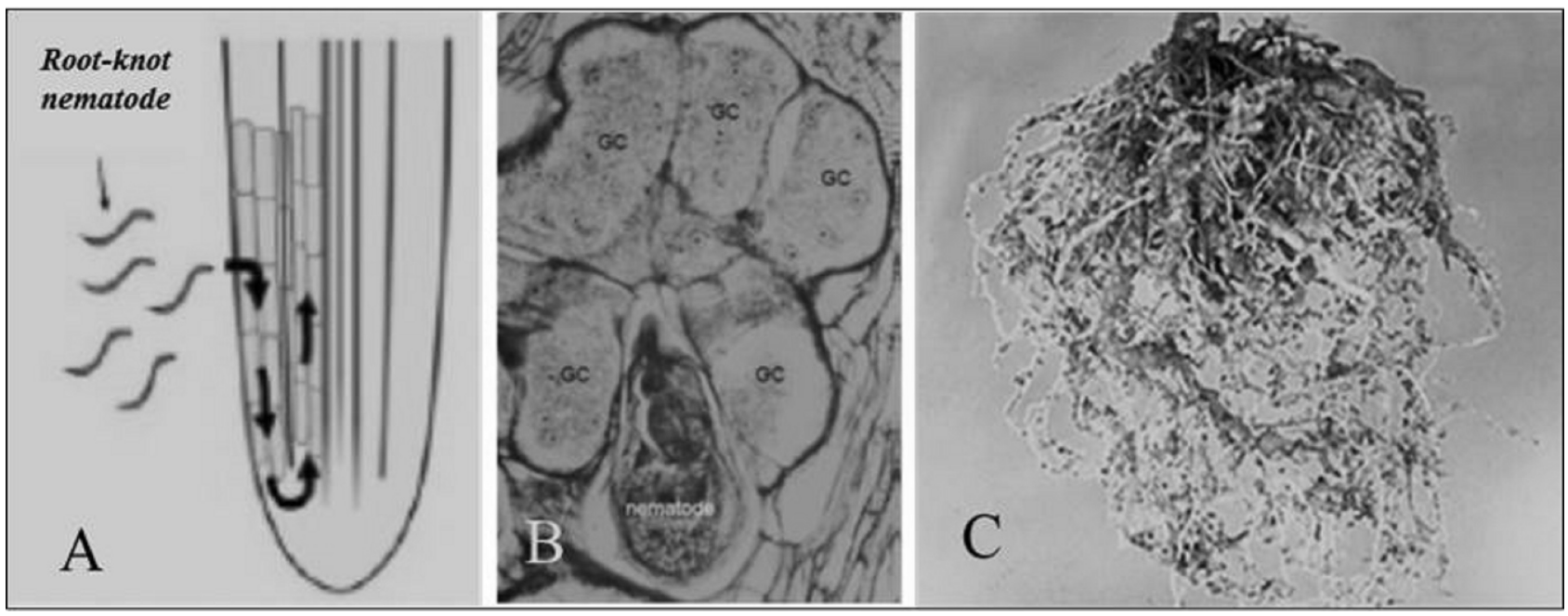

Fig. 1. Development of the giant cells and the gall. (A) Nematode penetration and intercellular movement inside the root, (B) cross section of the multinucleate giant cells initiated by the female RKN and (C) gall formation surrounding the giant cells. Image A, B and C have been taken from Schumann and D'Arcy (2010).

Usually, sedentary females continue feeding into the GCs and lay eggs on the root surface whereas males leave the root. So, it is essential for the nematode to persist in the feeding site (GCs) during the sedentary phases for the developing and reproducing next generation (Jaubert et al. 2005). Finally, at extreme conditions the GCs exhibits hyperplasia and hypertrophy leading to form a stereotypic root-knot galls (Fig. 1C).

\section{Molecular mechanism of establishing nematode-induced feeding site (NFS)}

Abundant effector molecules have been reported by Davis and Mitchum (2005) and thought that these effectors initiate the feeding site. Jaubert et al. (2005) reported a molecule Mi-CRT, localized at the tip of the nematode stylet, and at the cell wall of the GCs, supporting oesophageal molecule insertion during the establishment of NFS. Similar studies identified different candidate molecules from oesophageal gland of M. incognita (Huang et al. 2005; Mitreva-Dautova et al. 2006; Schaff et al. 2007). Authors speculated that those molecules could be acting as a facilitator of entering and intercellular movement of the RKN at the early phases of the parasitism. However, presence of different candidate molecules in the nematode secretions supports the thoughts of the NFS formation as well as hypothesis of the parasitism (Ferreira et al. 2004; Dubreuil et al. 2007; Bellafiore et al. 2008). Moreover, a molecule associated to rhizobial Nod factor acting as an initial signal of RKN-plant parasitism (Weerasinghe et al. 2005). Recently, gene expression patterns during initiation of the NFS have been examined by various approaches such as transcriptomic analysis (Dubreuil et al. 2007), promoter-trapping strategies (Favery et al. 2004), in situ hybridizations (Gal et al. 2006), quantitative RT-PCR and in situ RT-PCR (Wieczorek et al. 2014). Identification of pathogen effectors, function of the effectors in the NFS development as well as mechanism of the parasitism will be more fascinating with the technical advancement in future.

\section{NATURAL RESISTANCE GENE IN CONTROLLING RKN}

In tomato, several independent single dominant $R$ genes have been identified and mapped in different chromosomes, which are designated as $M i-H T, M i-1, M i-2, M i-3$, Mi-4, Mi-5, Mi-6, Mi-7, Mi-8 and Mi-9 (Table 1). Those resistance genes are commercially used in tomato breeding programs in controlling three main RKN species, $M$. 
Table 1. Identified RKN resistance genes in tomato.

\begin{tabular}{|c|c|c|c|}
\hline Gene & Properties & Genetics & References \\
\hline$M i-H T$ & Resistance to southern $\mathrm{RKN}$ at $32^{\circ} \mathrm{C}$ & $\begin{array}{l}\text { Mapped to short arm of chromosome } \\
6 \text {; homologue of } M i-1 \text { and } M i-9 \text { or a } \\
\text { new gene }\end{array}$ & Wang et al. (2013) \\
\hline$M i(M i-1)$ & $\begin{array}{l}\text { Resistance to several species of } \\
\mathrm{RKN} \text {; resistance lost at }>30^{\circ} \mathrm{C}\end{array}$ & $\begin{array}{l}\text { Mapped to short arm of chromosome } \\
6 ; \text { cloned }\end{array}$ & $\begin{array}{l}\text { Aarts et al. (1998), } \\
\text { Milligan et al. (1998), } \\
\text { Vos et al. (1998) }\end{array}$ \\
\hline$M i-2$ & Resistant to $M$. incognita at $32^{\circ} \mathrm{C}$ & $\begin{array}{l}\text { Not linked to } M i \text { or } M i-3 \text { linked to } \\
M i-8\end{array}$ & Cap et al. (1993) \\
\hline$M i-3$ & $\begin{array}{l}\text { Resistance to } M i \text {-virulent } M . \\
\text { incognita } 557 \mathrm{R}\end{array}$ & $\begin{array}{l}\text { Mapped to short arm of chromosome } \\
12 \text {; linked to } M i-5\end{array}$ & $\begin{array}{l}\text { Yaghoobi et al. (1995) } \\
\text { Yaghoobi et al. (2005), }\end{array}$ \\
\hline$M i-4$ & $\begin{array}{l}\text { Resistant to } M \text {. javanica and } \\
\text { M. incognita at } 32^{\circ} \mathrm{C}\end{array}$ & - & Veremis and Roberts (1996a) \\
\hline$M i-5$ & $\begin{array}{l}\text { Resistant at } 32^{\circ} \mathrm{C} \text { to } M \text {. incognita } \\
\text { and } M \text {. javanica }\end{array}$ & Linked to $M i-3$ on chromosome 12 & Veremis and Roberts (1996b) \\
\hline$M i-6$ & Resistant to $M$. incognita at $32^{\circ} \mathrm{C}$ & Linked to $M i-7$ & Veremis and Roberts (1996b) \\
\hline$M i-7$ & $\begin{array}{l}\text { Resistant to } M i \text {-virulent } \\
M \text {. incognita } 557 \mathrm{R} \text { at } 25^{\circ} \mathrm{C}\end{array}$ & Linked to $M i-6$ & Veremis and Roberts (1996b) \\
\hline$M i-8$ & $\begin{array}{l}\text { Resistant to } M i \text {-virulent } \\
M \text {. incognita } 557 \mathrm{R} \text { at } 25^{\circ} \mathrm{C}\end{array}$ & Linked to $M i-2$. & Veremis and Roberts (1996b) \\
\hline$M i-9$ & $\begin{array}{l}\text { Heat stable resistance to } \\
\text { M. javanica, } M \text {. arenaria and } \\
\text { M. incognita }\end{array}$ & $\begin{array}{l}\text { Mapped to short arm of chromosome } \\
6 \text {; cloned }\end{array}$ & $\begin{array}{l}\text { Ammiraju et al. (2003) } \\
\text { Jablonska et al. (2007), }\end{array}$ \\
\hline
\end{tabular}

Incognita, M. javanica and M. arenaria. Limited diversity of such $R$ genes is the major concern in tomato breeding programmes. Currently, all available tomato cultivars either fresh-market or processing carry the single dominant $R$ gene $M i$ (Williamson and Roberts 2009). It has been thought that the gene $M i$ is an only source of resistance to RKN for all existing tomato cultivars worldwide for the last 60 years and considered as a very durable $R$ gene. Though the gene is an exceptional example of the use of host resistance to diminish the necessity of pesticides application (Sorribas et al. 2005), the resistance breaking or overcoming has been occurred due to repeated planting of resistant cultivars having $M i$ genes. It might be due to the emergence of $M i$-virulence nematode populations by either exerted selection pressure or genetic drift. Breaking down of $R$ genes imposed plant breeders to investigate novel sources of resistance and currently, fifty four defence related putative genes have been identified those are up-regulated during RKN infection in tomato including peroxidases, chitinases, extensins and proteinase inhibitors and glycosyltransferases (Schaff et al. 2007). On the other hand, callose or lignin synthesis at plant cell wall acts as a physical barrier of stylet penetration in where glycosyltransferases genes may play a role in cell wall synthesis reported by Egelund et al. (2004). However, resistance mediated by the $M i$ gene is associated with several factors including soil temperature, gene dosage and the state of resistance loci whether the loci in homozygous or heterozygous. The efficacy of resistance should be reflected on a long-term basis in order to define its durability. The durability of resistance mostly depends upon the occurrence of virulence isolates of nematode. Djian-Caporalino et al. (2011) reported that a propagative fitness cost is linked to nematode virulence against $M i-1$ in tomato. Although the resistance is broken down, it may be conserved in some conditions if the virulent nematodes are counter-selected in susceptible plants (Djian-Caporalino et al. 2011). Therefore, the durability should be assessed either by long-term cropping of resistant cultivars or by cultivating resistant cultivars under high inoculum pressure. 


\section{THE MECHANISM OF NATURAL RESISTANCE}

Naturally, plants evolve various mechanisms to protect themselves from a wide range of pathogens such as nematodes, fungi, bacteria, oomycetes, and viruses. The plant has innate immune system, can recognize broadly Pathogen Associated Molecular Patterns (PAMPs, also called Microbe Associated Molecular patterns-MAMPs).
Actually, this detection responds to slowly evolving PAMPs, such as collagenase resulting defence reaction, called PAMPs triggered immunity (PTI, Fig. 2A). PTI may be the first line of defence response of plant to pathogens, which is initiated by the extracellular receptor proteins; receptor like kinase (RLK) and/or receptor like protein (RLP) (Chisholm et al. 2006). On the other hand, the second line of defence against specific pathogen races are coordinated by the intracellular proteins that contain a

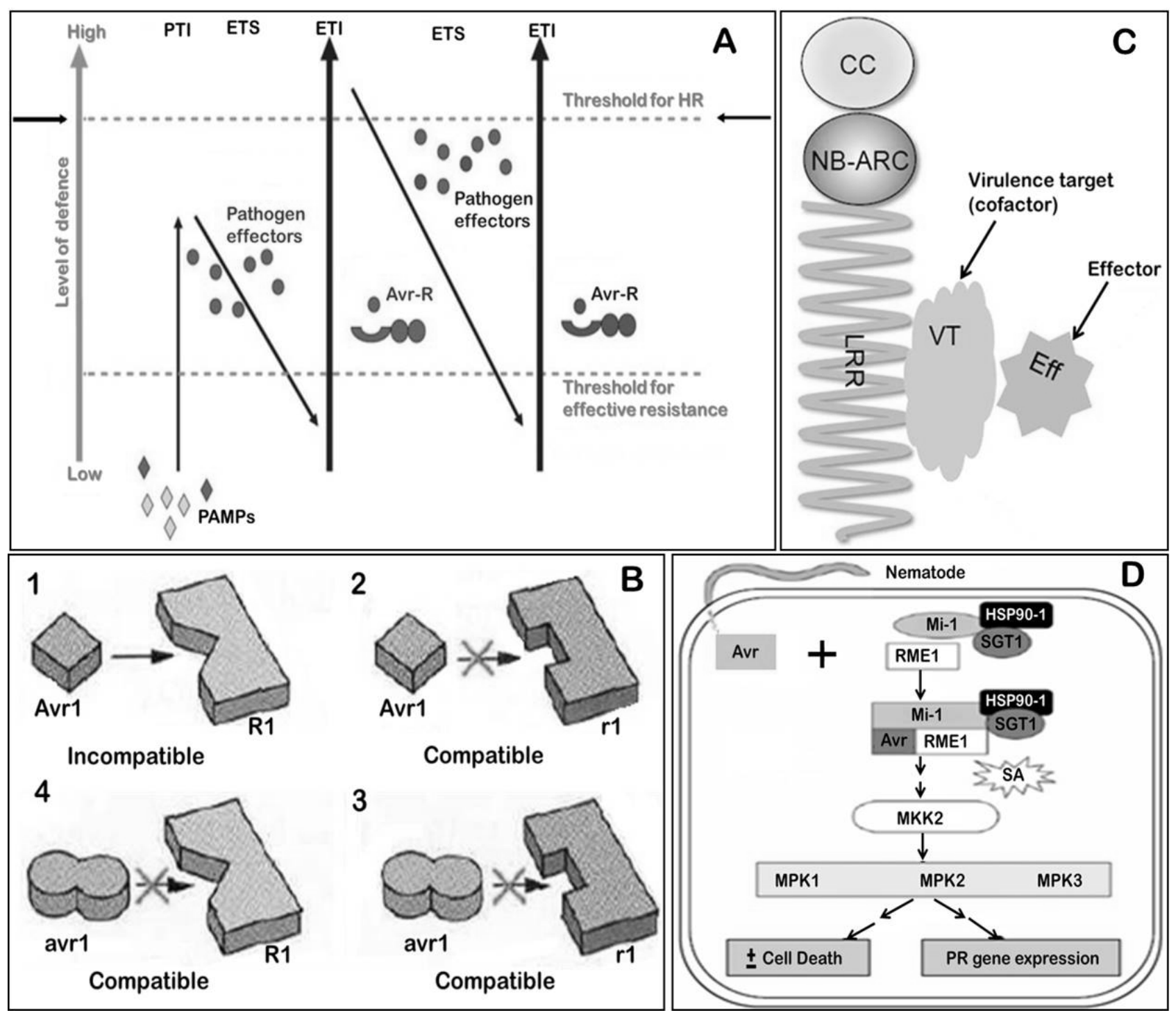

Fig. 2. The mechanism of plant-microbe interaction. A zigzag model illustrates the quantitative output of the plant immune system during interact with microbe (A), Gene-for-gene concept to explain specificity of ETI (B), guard hypothesis of the $R$ genes in general (C), and guard hypothesis of $M i-1$ gene in RKN-plant interaction (D). (A and D) modified with kind permission from Jones and Dangl (2006) and Bhattarai et al. (2007), respectively. (B and C) Idea adapted from Dodds et al. (2006) and Jones and Dangl (2006), respectively. 
nucleotide binding site (NBS) and either toll-like interleukin receptor (TIR) or coiled-coiled (CC) domain plus leucine-rich repeats (LRRs) (Chisholm et al. 2006), but not always the case. It is thought that the plants have plenty of receptor proteins those acting against different pathogens (Yang et al. 2008). For example, Mi-1-based resistance is triggered by the member of NBS-LRR class protein that does not have an N-terminal toll-interleukin receptor-like (TIR) domain. During second line of defence two modes of pathogen interaction; direct and indirect has been revealed by the previous research (Caplan et al. 2009).

\section{Direct interaction}

Receptor proteins directly interact with effectors maintaining the gene-for-gene interaction theory as described by Flor (1971). Gene-for-gene interaction is explained in various crops to confer highly effective qualitative resistance. Qualitative resistance refers to vertical resistance or race-specific resistance mediated by a single dominant $R$ gene. Race-specific resistance always shows a stronger pattern of selection compare to sets of non race-specific resistance (Bakker et al. 2006). This concept refers to a receptor-ligand model in where plant activate their defence mechanism upon recognition of pathogen-derived product $A v r$ gene by the $R$ gene (Van der Biezen and Jones 1998) (Fig. 2B; event number 1, matching of $R$ gene with $A v r$ gene). Although several pairs of cognate $R$ - and $A v r$ - genes are identified, direct interaction may be proven only in four cases (Jia et al. 2000; Deslandes et al. 2003; Dodds et al. 2006; Ueda et al. 2006) (Fig. 2B). Actually, the matching of $R$ gene with $A v r$ gene triggers the defence response resulting in visible localized programmed cell death (PCD) culminating a hypersensitive response (HR) (Heath 2000). For example, if the elicitors/effectors, product of $A v r$ gene from the nematode enter the plant cells that possess $R$ gene $M i$, the product of $M i$ gene recognize the product of $A v r$ gene lead to a HR known as incompatible interaction (Fig. 2B; event number 1, matching of $R$ gene with $A v r$ gene) as described in a model system of Meloidogyne-resistant tomato plant (Bleve-Zacheo et al. 2007).

It is thought that the HR is the result of the production of oxidative burst, occurs rapidly after nematode invasion, with a second burst associated with the HR reaction only detectable in the incompatible tomato-nematode interaction (Melillo et al. 2006). So, due to incompatible interaction, there is no feeding site formation, no giant cell and no or very few reproduction. Molinari (2008) studied the Meloidogyne-tomato incompatible interaction under in vivo and in vitro conditions and reported that resistant roots always showed HR to RKN attack. In addition, Branch et al. (2004) constructed transgenic tomato plants carrying $M i-1$ with the expression of $N a h G$ (encode salicylate hydrolase that degrades salicylic acid) that showed HR upon nematode infection and concluded that salicylic acid is an important component of the downstream signalling to trigger resistance. On the contrary, feeding site formation, giant cell development and reproduction of nematodes are usually happen during compatible interaction (Fig. 2B; event number 2-4, mismatching of $R$ gene with $A v r$ gene). Physiological and molecular changes associated with the maintenance of giant cells during compatible interaction are described details in previous study (Bleve-Zacheo and Melillo 1997) and we are not going to discuss here.

\section{Indirect interaction}

In many cases gene-for-gene interaction does not explain effectors detection directly. Then an alternative model "guard hypothesis" suggested in where resistance proteins interact with effectors indirectly (Dangl and Jones 2001). Mechanism of guard hypothesis (Fig. 2C) in where $R$ genes do not directly recognize pathogen effectors; rather detect them indirectly via their perturbation of host proteins. The virulence factors/protein of the plant are targeted by Avr genes (effectors of pathogen) other than those encoded by $R$ genes, but the virulence protein is guarded by a $R$ gene that detect any kind of modifications elicited by the pathogen effectors. As a result, a defence response cascade is then induced, often terminating in a HR (Cabrera Poch et al. 2006). In contrast, the occurrence of susceptibility while there is no guarding or no $R$ gene present in the plant targeted for the Avr genes, often resulting in a disease. For example $r m e 1$, a recessive gene resistance to Meloidogyne species, which is unlinked to Mi-1 (de Ilarduya et al. 2001), and compromised $M i-1$-mediated resistance. Since the gene product of RME1 
still unknown; the authors guessed that it may be a protein kinase performing either upstream of $M i-1$ or at the initial stage of the signal transduction pathway. This is stressing the possibility of targeting RME1 by the Avr genes of different species of nematode, aphid and whitefly, and subsequently, the detection of changes of RME1 may occur by a $R$ gene $M i-1$ (Fig. 2D). As a result, activates a signalling cascade leading to express pathogenesis related (PR) genes and/or program cell death. Another example is Rcr3 (apoplastic cysteine protease), a common virulence target for fungus and nematode, guarded by the tomato resistant protein $C f 2$ and $\mathrm{HR}$ have been shown to elicit during modification of Rcr3 by Cladosporium fulvum (Rooney et al. 2005; Lozano-Torres et al. 2012), indicating indirect interaction of $C f 2$ with the pathogen (Fig. 2C).

\section{Co-evolution of $R$ - and $A v r$-gene}

The adapted pathogens usually secretes a collection of effector proteins into host cells that often act to suppress PTI by interfering either in recognition or down regulate signalling pathway, leads to effectors triggered susceptibility (ETS; Fig. 2A). Since plants have numerous receptor proteins some of those may recognize newly evolve effectors and activate strong defences, called effectors triggered immunity (ETI; Fig. 2A). The best example is MAP-1, RKN effector proteins which were identified in near-isogenic lines of $M$. incognita selected on plants carrying Mi-1 resistance gene (Semblat et al. 2001), and subsequently, showed correlation to nematode avirulence (Castagnone-Sereno et al. 2009), indicating ETI response in association with the $R$-gene $M i-1$ (Fig. 2A). Similarly, $C g-1$ from Meloidogyne javanica also appears to be involved in ETI in host plant carrying Mi-1 resistance gene. It was found that avirulent $M$. javanica strain gaining virulence due to loss of $C g-1$ while culturing continuously on resistant tomato cultivars (Gleason et al. 2008). It can reproduce on tomato plant carrying Mi-1 resistant gene, indicating role of $\mathrm{Cg}$ - $\mathrm{l}$ in ETI (Fig. 2A). Recent studies from $\mathrm{Y} 2 \mathrm{H}$ screen showed that cyst nematode effectors physically interact with different host protein kinases (Maier et al. 2013). Though it is unknown, whether the nematode effectors interact with kinase activity or this interaction is required for gaining virulence of effectors.
Anyway, pathogens can modify the resistance response by masking or delivering novel effectors to avoid defence elicitation, at risk of a fitness cost associated with loss of those effectors and the process of effectors recognition. This phenomenon can be termed as conflict of coevolution of pathogen effectors and host resistance genes (Jones and Dangl 2006, Fig. 2A). This conflict of coevolution carries practical implication for resistance durability and for future resistance engineering. Therefore, understanding the mechanisms underlying the co-evolution between nematode $A v r$ genes and host $R$ genes is essential for the development of durable crop protection strategies.

\section{INDUCED RESISTANCE TO RKN}

It is well-known that after infecting by a microbial pathogen, susceptible plants evolve an enhanced resistance to secondary infection. This phenomenon termed as induced resistance that is further split into induced systemic resistance (ISR) and systemic acquired resistance (SAR). However, few study has been carried out to date on induced resistance to plant parasitic nematodes, whereas most of the existing reports are referred to induced resistance against RKN in tomato (Cooper et al. 2005; Javed et al. 2007). In addition, virus inducing gene silencing (VIGS) study showed that a glycosyltransferase gene can enhance $\mathrm{Mi}-1$ mediated resistance to RKN in tomato (Schaff et al. 2007). Bhattarai et al. (2007) also reported that nematodes couldn't capable to persist and to eat on tissues without regulating cytosolic heat shock protein $H s p 90$ expression, indicating $H s p 90$ is a required element as a molecular tool to act together Rarl and Sgtl in certain $R$ gene reactions.

\section{Induced systemic resistance (ISR)}

Induced systemic resistance is tempted by non-pathogenic rhizobacteria that is independent of salicylic acid, but dependent on jasmonic acid (JA) and ethylene induction. It is mainly characterized by the colonization of plant roots by the plant-growth-promoting-rhizobacteria (PGPR) mediating via jasmonate or ethylene activation pathway (Pieterse and Van Loon 2007). Several experiment showed that JA and neem (Azadirachta indica) formulations have 
been accounted for promoting a restriction to RKN invasion on tomato roots. Cooper et al. (2005) reported that use of JA induces a universal resistance reaction of tomato plants resulting decreases avirulent nematode reproduction on susceptible plants. Furthermore, JA-dependent defences shown to be heat-stable, the efficacy of $M i$-mediated resistance were dampen but not excluded at $32^{\circ} \mathrm{C}$. It seems that use of JA increased $M i$-mediated resistance at high temperature, but did not suppress the virulent nematode strains studied by Cooper et al. (2005).

\section{Systemic acquired resistance (SAR)}

SAR generally develops a broad-spectrum systemic resistance locally or systemically in reaction to the pathogen attack or the treatment application with chemicals mediated by a SA activation pathway. SAR is associated with increasing SA level by generating reactive oxygen species (ROS), enhancing activities of superoxide dismutase (SOD) and guaiacol peroxidase (GPOX), phytoalexin biosynthesis, accumulation of pathogenesis-related (PR) proteins (Pieterse and Van Loon 2007; Sahebani and Hadavi 2009; Molinari et al. 2014). Recent study reported that chemical and microbial elicitors such as $\beta$-aminobutyric acid (BABA), Salicylic acid (SA), and Pseudomonas fluorecens CHAO significantly reduced the RKN infection in tomato seedlings (Sahebani and Hadavi 2009). Herman et al. (2007) found that acibenzolar-S-methyl (ASM)induced larger number of defense genes during second application compared to first application, indicating earlier induction of resistance genes does not negotiate the capability of the plant to react on later inductions. Meloidogyne incognita infection was demonstrated to elicit SAR in shoots of resistant plants carrying Mi-l gene in where SA exogenously added as a soil drench (Molinari et al. 2014). Interestingly, SA also has down regulatory role in effecting nematode-resistance gene $\mathrm{Mi}-1$ so far have NBS-LRR domains (Sobczak et al. 2005; Li et al. 2006). However, Bhattarai et al. (2007) published a combined results including NBS-LRR protein interactions and suggested a model for the Mi-1 signalling pathway as illustrated in Fig. 2D.

\section{LIMITATIONS OF NATURAL RESISTANCE}

Although the natural resistance is thought to be a unique strategy in controlling nematode invasions, but the consideration of economic, environmental and health issue may limit the utility of natural resistance. Resistance triggered by some genes is not fully completed therefore a proportion of nematodes are able to survive and reproduce. Besides, the introgression may confer yield penalties due to introduce of detrimental agronomic traits. For example, linkage drag of the wild relative genes caused poor-quality tomato fruit while introgressed Mi-1 from Solanum peruvianum to a susceptible elite cultivars. It should also consider that the insertion of transgenes may also raise unintended detrimental characters. Major concern for the plant breeders is that overcoming resistance of $R$ genes due to evolve virulent races of the associated pathogens. In addition, single dominant $R$ genes are naturally effective to a limited range of species; many are functional only against specific pathotypes, but crops are often exposed to a wider range of parasites.

\section{Genetics of virulence in nematodes}

Mitotic parthenogenesis is the way of reproduction of the most RKN species such as M. incognita, M. javanica and $M$. arenaria, a machinery producing clonal offspring in which eggs are fertilized via mitotic process, not meiotic. A few RKN species, including M. hapla are bred by facultative meiotic parthenogenesis. So, parthenogenic RKN species have lower but still substantial variability exists within and between species for their host range as well as virulence/avirulence motion. A well characterized example is the revealing of virulence RKN populations on plants those carrying $\mathrm{Mi}$ gene after several generations (Roberts and Thomason 1986; Ogallo and McClure 1996; Molinari and Miacola 1997). Virulence populations have been previously detected from avirulent strains after repeated cultivation of resistant tomato plants under field (VerdejoLucas et al. 2009) as well as greenhouse condition (Triantaphyllou 1987; Jarquin-Barberena et al. 1991), indicating many $\mathrm{RKN}$-virulence genes are involved. Another study with soluble proteins from closely related isolates of virulent/avirulent female nematodes showed 
that there is an extra protein spot in the avirulent female on 2-D polyacrylamide gels. The gene encoding this protein would be a candidate for RKN avirulence gene (Dalmasso et al. 1991). Unluckily, the inheritance of avirulence or virulence cannot be verified directly due to the absence of sexual reproduction, but then look forward to developing new approaches and techniques such as transformation of phytopathogenic nematodes. In addition to that the wider evolutionary ability of the pathogen is another quality to influence resistance durability, but major hurdle is that the traditional Mendelian genetic analyses are not feasible for the factors determining host range as well as (a)virulence of pathogen. So, the likely durability of $R$ genes can be anticipated only by the assessment of a pathogen's broader evolutionary potential.

\section{Failure to trigger resistant response by the $R$ genes}

The incompatible interaction is often altered to the compatible interaction due to sequester of $A v r$ genes by the pathogen secreted enzymes. So, the evolution of effectors is influenced by their recognition and contribution to virulence while circumvent recognition by the host resistance genes. Changes in effectors protein sequence via mutation can potentially disrupt the physical interaction with the resistance protein. For example, $M$. incognita juveniles of the Mi-1-avirulent strain produced Mi-1-virulent progeny while soaked in dsRNA corresponding to part of the predicted $C g-l$ (DNA fragment) transcript (Gleason et al. 2008). It is strongly suggested that silencing effector component $\mathrm{Cg}$ - $\mathrm{l}$ which is corresponding to $\mathrm{Mi}-\mathrm{l}$ gene leads to the achievement of virulence in nematode. Besides, Sgtl (suppressor of G-two allele of Skpl) and $H s p 90$ (heat shock protein 90) requires for $\mathrm{Mi}$-1-mediated pest resistance, which are known to contribute activation of resistance signaling pathways (Bhattarai et al. 2007). So, silencing of $S g t 1$ and $H s p 90$ proteins somehow in host cell may failure to activate signaling pathway by the $\mathrm{Mi}-1$ gene. However, there are multiple genetic strategies such as masking effectors, modification of receptor proteins, production of antioxidant enzymes and intercept downstream signaling by which a nematode can acquire the ability to circumvent resistance. For example, loss of a nematode gene product Avr gene (by mutation) could result in failure of recognition by the $R$ gene. Otherwise, gaining function to suppress the HR, could repress the capability of plants to trigger resistance. Antioxidant enzymes secreted by RKN may have role to circumvent the HR in resistant roots. Molinari (2009) identified a virulent isolate of M. incognita, which has capability to secret antioxidant enzymes including catalase, superoxide dismutase and peroxidase, but it is not clear whether the enhanced antioxidants activities contributing to the virulent phenotype or whether they are a side effect.

\section{Temperature sensitivity of the $\boldsymbol{R}$ genes}

At high soil temperature $\left(>28^{\circ} \mathrm{C}\right) \mathrm{Mi}-1$ gene doesn't function well (Dropkin 1969; Ammati et al. 1986), may play a role to delimit its utility worldwide. Although Mi-gene confers resistance to M. incognita, M. javanica, and $M$. arenaria under optimum conditions (Brito et al. 2007; Thies et al. 2008), but some strains of M. enterolobii have overcome the $M i$-mediated resistance. It makes challenging to manage this species, particularly in organic farming systems where chemical control is not an option (Kiewnick et al. 2009). The in vitro alterations of the cloned genes can be an alternative strategy to control a range of nematodes. For example, $M i$-genes have the partial resistance to nematode species M. hapla, but possibility to improve the resistance level or the temperature sensitivity by changing the structure, expression level and/or signal transduction pathway of the genes.

\section{DURABILITY AND LIFESPAN OF THE $R$ GENES}

Two key factors are governed the durability of an $R$ gene in plants, firstly, the relative importance of the recognition of pathogen effectors determining overall pathogen fitness. The question is why resistant genes have been broken-down. Usually, pathogen strains often completely lose the corresponding avirulence genes from their genome by genetic changes. The consequence of loss of avirulence activity turns to virulence resulting overall fitness of pathogen. In this case, recognition of effector might be a 
strong factor in determining the durability of the resistance. Besides, the pathogen may have multiple effectors that provide a redundant virulence activity. On the basis of above concept researcher should assess the fitness contributions of the corresponding effectors to predict the relative durability of an $R$ gene in advance. Secondly, the capability of the effectors to escape directs recognition undertaking prompt structural changes in order to keeping them virulence. Direct recognized effectors may be able to mutate to circumvent their recognition despite the fact that still contributing to the virulence. Therefore, indirect recognition may have the most important involvement to pathogen fitness; apparently offer the best recognition targeting durable resistance. Since, PAMPs (or MAMPs) are broadly conserved and essential for the pathogens, appear to be the best targets for recognition than unessential effectors. Although, the PAMPs are absolutely a primary target of plant immune systems, but the ability of the pathogens to dampen PAMP-triggered immunity, has alleviated their importance as elicitors of durable resistant reactions. However, engineering of PAMP recognition may be an imperative area for future creativity in molecular plant breeding. Strategies need to be developed for the best use of $M i$ and other resistance genes as well as prolonged their useful lifespan. Now it is a big question to the plant breeder- Is pyramiding several resistance genes into elite cultivars the best solution or will it accelerate the spreading of super-virulent nematodes? Nevertheless, many $R$ genes appear to be innovative mode with infrequent sequence exchange, suggesting that those genes may not be broken-down quickly due to natural assortment of the $R$ genes. Thus the natural diversity of the $R$ genes is a potentially valuable source for durable resistance (Chen $e t$ al. 2010).

\section{OPPORTUNITY TO IMPROVE THE DURABILITY OF THE $R$ GENES}

\section{Pyramiding of $\boldsymbol{R}$ genes}

$R$ genes are more desirable in breeding program due to simplicity of its introgression. But it can be broken down relatively quick because of evolution of new races of pathogens. The goal of the gene pyramiding is to add resistant genes into the plants to counteract wide range of biotypes or races that are existing or prevalent in future. Pyramiding genotypes usually possess more than an effective $R$ gene so that pathogen replication will be limited, if individuals are existent that have lost avirulence for one of the stacked $R$ genes. Traditional breeding has been a useful strategy yet to transfer desired genes, but now it is also possible by the transgenic process. Transgenic strategy allows to identify and to deploy various $R$ genes either from wild germplasm or sexually incompatible species. It has some limitation due to fact that all $R$ genes may not work properly in heterologous condition, probably the guarded host protein is missing, or because of pathogen-independent resistance protein instigation in the heterologous system. This is not the case always, because Mi-1.2 gene in tomato (Solanum lycopersicum) belongs to NB-LRR class of resistance genes able to elicit resistance in heterologous system as it is resistance to RKN (Meloidogyne spp.), potato aphid (Macrosiphum euphorbiae), and sweet potato whitefly (Bemisia tabaci) (Fiona et al. 2006). Another example is that the $M i-3$ gene elicits resistance to $M i-1$-virulent nematode races and it may also confer heat-stable resistance. Therefore, transferring of $M i-3$ gene to cultivated tomato is desired to complement the qualities of $M i-1$. In addition, pyramiding of $R M j a$ gene from Almond with the background of Ma (in Myrobalan) and RMia (in peach) protected from RKN affecting Prunus, i.e., M. arenaria, $M$. incognita, and $M$. javanica (Ghelder et al. 2010). However, this study could be a worthy of pyramiding strategy for the rootstock material which hold promising of durable resistance.

\section{Marker-assisted breeding}

Use of host resistance to control nematodes has been preferred as an environment friendly and cost-effective approach of the alternative to chemical control. So, discover markers associated with genes or quantitative trait loci (QTLs) link to RKN, either preventing growth of NFS or avoiding invasion of $\mathrm{J} 2$ could be an alternative approach to improve selection efficiency in breeding program. Genetic markers and linkage maps can facilitate the determination and localization of interactive genes or 
QTLs affecting the specific trait. Identification and localization of effective genes or QTLs might be accelerated either introgression into desired genetic backgrounds through marker-assisted backcrossing (MAB) or sequencing via cloning. Marker assisted selection (MAS) may not only gear up the process of gene transfer, but it also may promote pyramiding of effective genes from diverse genetic backgrounds. Therefore, MAS is an effective methodology to improve crop significantly, more than what potentially is feasible via phenotypic selection. In this section, recent advancements of the discovery and use of molecular markers are discussed in relation to tomato breeding resistant to RKN. The last 20 years different types of molecular markers have been developed, including randomly amplified polymorphic DNAs (RAPDs), sequence-based markers such as cleaved amplified polymorphic sequences (CAPS) and sequence characterized amplified regions (SCARs) those are described in Table 2.

Tomato is one of the top most crop species for which genetic markers are used in commercial breeding by last few years (Foolad 2007). Yaghoobi et al. (2005) identified a tightly linked marker that is completely co-segregated with a single dominant gene $M i-3$ resistant to RKN. It can be used to identify $M i-3$ introgression in commercial tomato cultivars by either conventional breeding or cloning. So, the combination of Mi-3 and Mi-5 could be a novel resistance source against $M$. incognita and $M$. javanica at $30^{\circ} \mathrm{C}$. Dilip and Majid (2011) checked the efficacy of two co-dominant CAPS markers (Mi23 and
REX-1) and two co-dominant SCAR markers (Mi23 and $\mathrm{MiF} 3 / \mathrm{R} 3)$ using homozygous resistant (NC123S) and susceptible (NC1CELBR) genotypes. This study found mountain merit for the RKN resistance in heterozygous form. All markers except MiF3/R3 were useful in detecting $M i$ gene against the most devastating three nematode genotypes such as M. incognita, M. hapla and M. javanica. However, recent advances in tomato genome sequencing, promoting development of more effective markers to accelerate the process of MAS in tomato breeding are controlling RKN. In addition, agronomically vital resistance genes are likely to be identified and cloned in the past and near future as effort underway to map many resistance loci not only in tomato but also in pepper, including the $\mathrm{Me}$ genes resistance to Meloidogyne species (Djian-Caporalino et al. 2007). Chen et al. (2007) mapped degenerated primers that have extremely conserved structures of known $R$-genes may be used to facilitate the cloning of pepper gene. The method has been applied successfully to clone the first putative RKN $R$-gene CaMi from Capsicum annuum. Finally, functional analyses confirmed the requirement of $\mathrm{CaMi}$ gene from hot pepper in tomato as a true $R$-gene triggered resistance to RKN.

\section{Comparative genomics facilitate the resistance}

Insight into the evolutionary history of parasitism is necessary to understand the mechanism of plant-nematode interaction. Comparative genomics of plant and free-living nematodes provide the essential information within the phylum Nematoda (Mitreva-Dautova et al. 2006). The

Table 2. Molecular markers linked to RKN resistance in tomato.

\begin{tabular}{|c|c|c|c|c|}
\hline Gene & Marker & Marker type & Marker ID & References \\
\hline$M i$ & CAPS & Co-dominant & Aps & Ammiraju et al. (2003) \\
\hline$M i$ & CAPS & Co-dominant & C8B & Ammiraju et al. (2003) \\
\hline$M i$ & CAPS & Co-dominant & REX-1 & Ammiraju et al. (2003) \\
\hline$M i$ & CAPS & Co-dominant & CT119 & Ammiraju et al. (2003) \\
\hline$M i$ & RAPD & Dominant & $\mathrm{C} 1 / 2$ & Devran et al. (2008) \\
\hline$M i$ & RAPD & Dominant & $\mathrm{C} 2 \mathrm{~S} 4$ & Devran et al. (2008) \\
\hline$M i-1$ & RAPD & Dominant & REX & Williamson et al. (1994) \\
\hline$M i-1$ & SCAR & Co-dominant & Mi23 & Seah et al. (2007) \\
\hline$M i-1$ & SCAR & Co-dominant & Pmi & Arens et al. (2010) \\
\hline$M i-3$ & SCAR & Co-dominant & TG-180 & Yaghoobi et al. (2005) \\
\hline$M i-3$ & SCAR & Co-dominant & TG-263 & Yaghoobi et al. (2005) \\
\hline
\end{tabular}


information from the phylum Nematoda enables us exploring the variability of parasitism genes in the field populations. This type of study actually facilitates to assess the selection pressure on the genes acting in parasitism. Positive selection has been already reported for parasitism genes in other plant pathogens (Weber and Koebnik 2006). Pathogenicity genes encoding for secreted proteins under such positive selection could be very useful for the studies of interactions with the target proteins from the host. Thus comparative genomics provide understanding of molecular basis of plant-nematode interactions.

A genome sequence of the RKN, $M$. incognita, a biotrophic parasite of many crops, including tomato, cotton, banana and coffee is almost completed (Abad et al. 2008; Opperman et al. 2008). Abad et al. (2008) reported the assembled sequence totalling $86 \mathrm{Mb}$ of this asexually replicating nematode exists in pairs of homologous but divergent segments. It advises that the primitive allelic regions in M. incognita are developing towards effective haploidic, resulting new mechanisms of the alteration. Moreover, the secretion of plant cell wall-degrading enzymes by $M$. incognita is so diverse and may originate from various horizontal gene transfers starting bacterial sources. The outcomes provide understandings of the alterations required by metazoans to effectively parasitize immune-competent plants and open the way of determining new anti-parasitic approaches (Abad et al. 2008). Data from different research will generate different prospects for comparative genomics of nematodes fit into diverse functional and biological traits. Understanding of the full genome sequencing of the pathogens and the host plant will definitely create new opportunities in order to study the interaction between RKNs and plants. However, discovery and functional study of avirulence genes are hampered by numerous factors intrinsic to plant-parasitic nematodes. For example, $M$. incognita replicates by mitotic parthenogenesis in where traditional heritable studies are not likely. Besides, their small size and obligate parasitic lifestyle make functional studies challenging. Currently, heterologous genes expression in a knockout background is possible with plant-parasitic nematodes using genome sequencing data, indicating identification of new avirulence genes. Consequently, corresponding $\mathrm{Mi}$ genes can be used in the cultivars, resulting the possibility of increasing durability of the existing $M i$ genes.

\section{Changing cultural practices}

Farmers usually use resistant cultivars continuously without following either crop rotation or applying integrated pest management (IPM) strategy resulting resistant cultivars lose their resistance capacity to the target pest. So, changing cropping pattern from monoculture to multiculture could regain durability of resistance in the field condition. Now-a-days, farmers won't follow the traditional crop rotation system because of huge cash flow by the several crops. In this case, farmers are advised to rotate the same cultivars having different resistance genes ( $R$ gene) to minimize the strong selection pressure. Besides, mixed host approaches (lines with different resistance genotypes are cultivated in a single field) may also offer durable resistance to some extent. Combining and/or interchanging either the use of pesticides or $R$-genes have also been recommended to increase the durability of crop resistance. Sorribas et al. (2005) reported that the Mi-genes can be a cost-effective alternative to methyl bromide in controlling RKN, if manage it in an appropriate manner. Effective management practices not only reserve its durability but also prevent the selection of virulent populations. In addition, field trial results of Verdejo-Lucas et al. (2009) showed that the efficiency of $M i$-gene in tomato rootstocks was reduced after cultivating three years sequentially in a plastic house, indicating potential requirement of rotation either crop or genotypes having different $R$ genes.

\section{GENETIC ENGINEERING AS ALTERATIVE STRATEGY TO DEVELOP NOVEL RESISTANCE}

Although the integration of natural resistance to elite cultivars is a major component of nematode management program, but there are many crops for which appropriate resistance loci are not available. As nematode resistance genes are identified and cloned, it may offer the possibility to transfer them to other hosts, but it may have the 
uncertainty to function effectively in heterologous conditions. Furthermore, gaining of virulence by the nematodes may diminish the efficiency of this strategy. To minimize this gap, several approaches are being developed to engineer artificial resistance. Firstly, engineer plants expressing genes that are detrimental to the nematode. Secondly, alter plants with specific genes of the nematode to block the establishment of NFS. Thirdly, transform plants with well-designed constructs to interrupt the process of feeding cell development, but an important requirement for this strategy is that the promoter must be very specific so that toxin can't destroy cells that are essential for the plant development. Fourthly, incorporate a second component, a neutralizing gene that is constitutively expressed in the plant except in feeding structures. For most of these strategies, it is too difficult to predict whether they will be effective as expected.

\section{Use of resistance genes from other species}

Resistance to RKN usually associated with the numerous dominant genes identified in several crop species such as pepper Capsicum annuum (Pegard et al. 2005), plum Myrobalan - carried Ma gene (Khallouk et al. 2011), taro Colocasia esculenta - carried cysteine proteinase inhibitor CeCPI (Chan et al. 2010). Cloning and transferring of these genes to tomato would be the novel sources of resistance in controlling RKN. So, developing novel resistance in transgenic plants via genetic engineering has been an alternative source of resistance to non-targeted pest. For example, the most popular and the extensive used Mi gene Mi-1 confers effective resistance to potato aphid while transferred to susceptible tomato. In addition, orthologs of the Arabidopsis precursor are already existing in many agriculturally important crops (Yamaguchi et al. 2006) indicating significant prospects of the crop improvement. However, combining both natural and engineered resistance into a single cultivar as well as investigating the biology of the nematode is needed to develop more durable control strategies for the future.

\section{Gene silencing}

Parasitism is an important strategy of RKN for their lodging, fooding and reproduction into root cells. RKN usually release variety of effector proteins to establish their parasitism and to keeping them virulent at the juvenile stage. Studies have shown that the nematode saliva contain an effector protein $16 D 10$ encoding gene for the parasitism (Huang et al. 2006), and Mi-crt and Mi-pg-1encoding gene for cell wall degrading enzyme polygalacturonase (Rosso et al. 2005). The RKN have employed diverse strategies to establish the parasitism in the plant roots using effector proteins, on the contrary, plants try to escape the parasitism. In this case, RNAi could be an effective resort to protect root cells from parasitism. RNAi strategy is

Table 3. Effect of RNAi at targeted genes of RKN in tomato.

\begin{tabular}{|c|c|c|c|c|}
\hline $\begin{array}{l}\text { Nematode } \\
\text { species }\end{array}$ & Gene function & RNAi effect & $\begin{array}{l}\text { Site of gene } \\
\text { expression }\end{array}$ & References \\
\hline M. artiellia & Chitin synthase & Delayed egg hatch & Eggs & $\begin{array}{l}\text { Fanelli et al. } \\
(2005)\end{array}$ \\
\hline M. incognita & Cysteine proteinase & $\begin{array}{l}\text { Delayed development. Decrease in } \\
\text { number of established nematodes. }\end{array}$ & Intestine & $\begin{array}{l}\text { Shingles et al. } \\
\text { (2007) }\end{array}$ \\
\hline M. incognita & Dual oxidase & $\begin{array}{l}\text { Decrease in number of established } \\
\text { nematodes. Decrease in fecundity. }\end{array}$ & $\begin{array}{l}\text { Presumed role in } \\
\text { extracellular matrix }\end{array}$ & $\begin{array}{l}\text { Bakhetia et al. } \\
\text { (2005) }\end{array}$ \\
\hline M. incognita & Splicing factor & $\begin{array}{l}\text { Reduced galling. Reduction in } \\
\text { number of females. }\end{array}$ & Unknown & $\begin{array}{l}\text { Yadav et al. } \\
(2006)\end{array}$ \\
\hline M. incognita & Integrate & $\begin{array}{l}\text { Reduced galling. Reduction in } \\
\text { number of females. }\end{array}$ & Unknown & $\begin{array}{l}\text { Yadav et al. } \\
(2006)\end{array}$ \\
\hline $\begin{array}{l}\text { M. incognita, } \\
\text { M. javanica, } \\
\text { M. hapla, } \\
\text { M. arenaria }\end{array}$ & $\begin{array}{l}\text { Secreted peptide } \\
\text { 16D10 }\end{array}$ & $\begin{array}{l}\text { Reduced galling. Decrease in } \\
\text { number of established nematodes. }\end{array}$ & $\begin{array}{l}\text { Subventral } \\
\text { pharyngeal glands }\end{array}$ & $\begin{array}{l}\text { Huang et al. } \\
\text { (2006) }\end{array}$ \\
\hline
\end{tabular}


considered as a tool in expressing dsRNA targeting parasitism gene in this case, leading to malfunctioning of either the parasitism or the development of NFS. Huang et al. (2006) reported that nematode parasitism gene was silenced when $16 D 10$ dsRNA ingested into tomato plant in vitro resulting in reduction of nematode infectivity. So, silencing targeted RKN parasitism genes in transgenic crops expressing dsRNA represents a defensible and durable RKN-resistant crop indicating evolving novel resistance traits. Transcriptomic analysis is also employed to identify the differentially expressed genes during nematode infection. Schaff et al. (2007) conducted a transcriptome analysis study including a resistance (cultivar Motelle homozygous for Mi-1) and a susceptible (Money-maker) tomato cultivar in where candidate gene glycosyltransferase was detected which was up-regulated six fold during invasion of $M$. incognita, but silencing of the candidate gene using VIGS technique abolished Mi-1-mediated resistance in the cultivar Motelle. Numerous resistance genes were identified by different studies those are silenced into plant cells using RNAi strategy. For example, $M i$-genes in tomato plants resistance to RKN that loss of its function via RNAi becoming susceptible to RKN as well as susceptible plants regaining resistance to RKN after transforming with sense $M i$ (Chen et al. 2006). Function of targeted genes, phenotypic changes by RNAi and site of gene expression are described in Table 3. However, RNAi strategy may provide crops with unparalleled broader resistance to RKN by disrupting the parasitic process.

\section{Use of Bt-protein}

Bacillus thuringiencis (Bt) Crystal (Cry) protein have the nematicidal effects that can confer resistance to endoparasitic nematodes. Li et al. (2007) conducted an experiment with the transgenic tomato plants carried Cry6A gene, in where they found the reproduction rate of $M$. incognita was fourfold lower than the control plant. Since transgenic plants expressing Cry protein triggers resistance to RKN indicating the potentiality in developing novel resistance for the host crops via genetic engineering.

\section{CONCLUDING REMARKS AND FUTURE PERSPECTIVE}

Integrating natural host resistance genes into elite cultivars is an everlasting alternative in controlling nematode as the cost-effective strategy. It is also effective while limitations on the use of nematicides because of arising health and environmental concerns. So, first step could be searching tomato germplasm as a new source of RKN resistance. Unlikely, model organism Arabidopsis has no natural resistance genes to nematodes, therefore, the huge range of molecular tools and currently available resources are remain unexploited. The availability of sequencing data from tomato species, which carry the nematode resistance, may be facilitated the characterization of the molecular basis of natural resistance. According to literature study, presently, Mi-1.2-based resistance is the most effective and understood one. Besides, developing markers tightly linked to RNK resistance can promote the introgression of novel resistance genes into elite cultivars. The outcome of the introgression of new resistance genes leads to either combine qualitative and quantitative resistance or pyramiding $R$ genes resulting durable resistance to RKN, an important plant pathogen. Problem is the overcoming all currently identified sources of resistance by the emerging virulent strains of RKN. Therefore, resistance based on antisense technology or expression of anti-nematode proteins via genetic engineering may be an additional source of resistance in future.

\section{ACKNOWLEDGEMENTS}

This work was supported by grants from Bangladesh Agricultural Research Council (BARC), Bangladesh. We acknowledge beneficial discussions with our colleagues at Bangladesh Agricultural Research Institute (BARI), including Dr. Mohammad Ziaul Hoque. The authors are grateful to A T M Tanjimul Islam (MSc student at the Wageningen University, Netherlands) for collecting current review. 


\section{REFERENCES}

Aarts MGM, Hekkert BTL, Holub EB, Beynon JL, Stiekema WJ, Pereira A. 1998. Identification of R-gene homologous DNA fragments genetically linked to disease resistance loci in Arabidopsis thaliana. Mol. Plant Microbe Interact. 11: 251-258.

Abad P, Gouzy J, Aury JM, Castagnone-Sereno P, Danchin EG, Deleury E, et al. 2008. Genome sequence of the metazoan plant-parasitic nematode Meloidogyne incognita. Nat. Biotechnol. 26: 909-915.

Ammati M, Thomason IJ, and Mckinney HE. 1986. Retention of resistance to Meloidogyne incognita in Lycopersicon genotypes at high soil-temperature. J. Nematol. 18: 491-495.

Ammiraju JS, Veremis JC, Huang X, Roberts PA, Kaloshian I. 2003. The heat-stable root-knot nematode resistance gene $\mathrm{Mi}-9$ from Lycopersicon peruvianum is localized on the short arm of chromosome 6. Theor. Appl. Genet. 106: 478-484.

Arens P, Mansilla C, Deinum D, Cavellini L, Moretti A, Rolland S, et al. 2010. Development and evaluation of robust molecular markers linked to disease resistance in tomato for distinctness, uniformity and stability testing. Theor. Appl. Genet. 120: 655-664.

Bakhetia M, Charlton W, Atkinson H, Mcpherson M. 2005. RNA interference of dual oxidase in the plant nematode Meloidogyne incognita. Mol. Plant Microbe Interact. 18: 1099-1106.

Bakker EG, Toomajian C, Kreitman M, Bergelson J. 2006. A genome wide survey of $R$ gene polymorphisms in Arabidopsis. Plant Cell 18: 1803-1818.

Bellafiore S, Shen Z, Rosso MN, Abad P, Shih P, Briggs SP. 2008. Direct identification of the Meloidogyne incognita secretome reveals proteins with host cell reprogramming potential. PLoS Pathog. 4: e1000192.

Bhattarai KK, Li Q, Liu Y, Dinesh-Kumar SP, Kaloshian I. 2007. The MI-1-mediated pest resistance requires Hsp90 and Sgt1. Plant Physiol. 144: 312-323.

Bleve-Zacheo T, Melillo MT, Castagnone-Sereno P. 2007. The contribution of biotechnology to root-knot nematode control in tomato plants. Plant Technology 1: 1-16.

Bleve-Zacheo T, Melillo MT. 1997. The biology of giant cells, p. 65-79. In: C. Fenoll, FMW. Grundler, SA. Ohl (eds.). Cellular and molecular aspects of plant-nematode interactions. Kluwer Academic Publishers, Dordrecht, Netherlands.

Branch C, Hwang CF, Navarre DA, Williamson VM. 2004. Salicylic acid in part of the Mi-1-mediated defense response to root-knot nematode in tomato. Mol. Plant Microbe Interact. 17: 351-357.

Brito JA, Stanley JD, Kaur R, Cetintas R, Di Vito M, Thies JA, et al. 2007. Effects of the Mi-1, N and Tabasco genes on infection and reproduction of Meloidogyne mayaguensis on tomato and pepper genotypes. J. Nematol. 39: 327-332.

Cap GB, Roberts PA, Thomason IJ. 1993. Inheritance of heatstable resistance to Meloidogyne incognita in Lycopersicon peruvianum and its relationship to the $M i$-gene. Theor. Appl. Genet. 85: 777-783.

Caplan JL, Zhu X, Mamillapalli P, Marathe R, Anandalakshmi R, Dinesh-Kumar SP. 2009. Induced ER chaperones regulate a receptor-like kinase to mediate antiviral innate immune response in plants. Cell Host Microbe 6: 457-469.

Castagnone-Sereno P, Semblat JP, Castagnone C. 2009. Modular architecture and evolution of the map-1 gene family in the root-knot nematode Meloidogyne incognita. Mol. Genet. Genomics 282: 547-554.

Cabrera Poch H, López R, Kanyuka K. 2006. Functionality of resistance gene Hero, which controls plant root-infecting potato cyst nematodes, in leaves of tomato. Plant Cell Environ. 29: 1372-1378.

Chan YL, Yang AH, Chen JT, Yeh KW, Chan MT. 2010. Heterologous expression of taro cystatin protects transgenic tomato against Meloidogyne incognita infection by means of interfering sex determination and suppressing gall formation. Plant Cell Rep. 29: 231-238.

Chen Q, Han Z, Jiang H, Tian D, Yang S. 2010. Strong positive selection drives rapid diversification of $R$-genes in Arabidopsis relatives. J. Mol. Evol. 70: 137-148.

Chen R, Li H, Zhang L, Zhang J, Xiao J, Ye Z. 2007. CaMi, a root-knot nematode resistance gene from hot pepper (Capsium annuum L.) confers nematode resistance in tomato. Plant Cell Rep. 26: 895-905.

Chen RG, Zhang LY, Zhang JH, Zhang W, Wang X, Ouyang $\mathrm{B}$, et al. 2006. Functional characterization of $\mathrm{Mi}$, a rootknot nematode resistance gene from tomato (Lycopersicon esculentum L.). J. Integr. Plant Biol. 48: 1458-1465.

Chisholm ST, Coaker G, Day B and Staskawicz BJ. 2006. 
Host-microbe interaction: Shaping the evolution of the plant immune response. Cell 124: 803-814.

Cooper WR, Jia L, Goggin L. 2005. Effects of jasmonateinduced defenses on root-knot nematode infection of resistant and susceptible tomato cultivars. J. Chem. Ecol. 31: 1953-1967.

Dangl JL, Jones JD. 2001. Plant pathogens and integrated defence responses to infection. Nature 411: 826-833.

Davis EL, Mitchum MG. 2005. Nematodes. Sophisticated parasites of legumes. Plant Physiol. 137: 1182-1188.

Dalmasso A, Castagnone-Sereno P, Bongiovanni M, de Jong A. 1991. Acquired virulence in the plant parasitic nematode Meloidogyne incognita. 2. Two dimensional analysis of isogenic isolates. Rev. Nematol. 14: 277-283.

de Ilarduya OM, Moore AE, Kaloshian I. 2001. The tomato Rmel locus is required for $\mathrm{Mi}-1$-mediated resistance to root-knot nematodes and the potato aphid. Plant J. 27: 417-425.

Deslandes LOJ, Peeters N, Feng DX, Khounlotham M, Boucher C, Somssich I, et al. 2003. Physical interaction between RRS1-R, a protein conferring resistance to bacterial wilt, and PopP2, a type III effector targeted to the plant nucleus. Proc. Natl. Acad. Sci. U.S.A. 100: 8024-8029.

Devran Z, Sogut MA, Gozel U, Tor M, Elekcioglu I. 2008. Analysis of genetic variation between populations of Meloidogyne spp. from Turkey. Russ. J. Nematol. 16: 143-149.

Devran Z, Söğüt MA. 2010. Occurrence of virulent root-knot nematode populations on tomatoes bearing the Mi gene in protected vegetable-growing areas of Turkey. Phytoparasitica 38: 245-251.

Dilip RP, Majid RF. 2011. A reexamination of molecular markers for use in marker-assisted breeding in tomato. Euphytica 184: 165-179.

Djian-Caporalino C, Fazari A, Arguel MJ, Vernie T, VandeCasteele C, Faure I, et al. 2007. Root-knot nematode (Meloidogyne spp.) Me resistance genes in pepper (Capsicum annuum L.) are clustered on the P9 chromosome. Theor. Appl. Genet. 114: 473-486.

Djian-Caporalino C, Molinari S, Palloix A, Ciancio A, Fazari A, Marteu N, et al. 2011. The reproductive potential of the root-knot nematode Meloidogyne incognita is affected by selection for virulence against major resistance genes from tomato and pepper. Eur. J. Plant Pathol. 131:
431-440.

Dodds PN, Lawrence GJ, Catanzariti AM, Teh T, Wang CIA, Ayliffe MA, et al. 2006. Direct protein interaction underlies gene-for-gene specificity and coevolution of the flax resistance genes and flax rust avirulence genes. Proc. Natl. Acad. Sci. U.S.A. 103: 8888-8893.

Dong LQ, Zhang KQ. 2006. Microbial control of plantparasitic nematodes: a five-party interaction. Plant Soil 288: $31-45$

Dropkin VH. 1969. The necrotic reaction of tomatoes and other hosts resistant to Meloidogyne: reversal by temperature. Phytopathology 59: 1632-1637.

Dubreuil G, Magliano M, Deleury E, Abad P, Rosso MN. 2007. Transcriptome analysis of root-knot nematode functions induced in the early stages of parasitism. New Phytol. 176: 426-436.

Egelund J, Skjøt M, Geshi M, Ulvskov P, Peterson B. 2004. A complementary bioinformatics approach to identify potential plant cell wall glycosyltransferase-encoding genes. Plant Physiol. 136: 2609-2620.

Fanelli E, Di Vito M, Jones J, De Giorgi C. 2005. Analysis of chitin synthase function in a plant parasitic nematode, Meloidogyne artiellia, using RNAi. Gene 349: 87-95.

Favery B, Chelysheva L, Lebris M, Jammes F, Marmagne A, De Almeida-Engler J, et al. 2004. Arabidopsis formin AtFH6 is a plasma membrane-associated protein upregulated in giant cells induced by parasitic nematodes. Plant Cell Rep. 16: 2529-2540.

Ferreira V, Molina MC, Valck C, Rojas A, Aguilar L, Ramírez G, et al. 2004. Role of calreticulin from parasites in its interaction with vertebrate hosts. Mol. Immunol. 4: 1279-1291.

Fiona LG, Lingling J, Gowri S, Stephanie H, Valerie MW, Diane EU. 2006. Heterologous expression of the Mi-1.2 gene from tomato confers resistance against nematodes but not aphids in eggplant. Mol. Plant Microbe Interact. 19: $383-388$

Flor HH. 1971. Current status of the gene-for-gene concept. Annu. Rev. Phytopathol. 9: 275-296.

Foolad MR. 2007. Genome mapping and molecular breeding of tomato. Int. J. Plant Genomics Article ID 64358.

Gal T, Kapulnik Y, Koltai H, Aussenburg E, Burdman S. 2006. Expression of a plant expansin is involved in the establishment of root knot nematode parasitism in tomato. Planta 224: 155-162. 
Ghelder C, Lafargue B, Dirlewanger E, Ouassa A, Voisin R, Polidori J, et al. 2010. Characterization of the RMja gene for resistance to root-knot nematodes in almond: spectrum, location, and interest for Prunus breeding. Tree Genet. Genomes 6: 503-511.

Gleason C, Liu Q, Williamson V. 2008. Silencing a candidate nematode effector gene corresponding to the tomato resistance gene $M i-1$ leads to acquisition of virulence. Mol. Plant Microbe Interact. 21: 576-585.

Goswami J, Pandey RK, Tiwari JP, Goswami BK. 2008. Management of Rootknot Nematode on Tomato Through Application of Fungal Antagonists Acremonium strictum and Trichoderma harzianum. J. Environ. Sci. Health 43: 237-240.

Heath MC. 2000. Hypersensitive response-related death. Plant Mol. Biol. 44: 321-334.

Herman MaB, Restrepo S, Smart CD. 2007. Defense gene expression patterns of three SAR-induced tomato cultivars in the field. Physiol. Mol. Plant Pathol. 71: 192-200.

Huang G, Allen R, Davis EL, Baum TJ, Hussey RS. 2006. Engineering broad root-knot resistance in transgenic plants by RNAi silencing of a conserved and essential root-knot nematode parasitism gene. Proc. Natl. Acad. Sci. U.S.A. 103: 14302-14306.

Huang G, Dong R, Allen R, Davis EL, Baum TJ, Hussey RS. 2005. Developmental expression and molecular analysis of two Meloidogyne incognita pectate lyase genes. Int. J. Parasitol. 35: 685-692.

Jablonska B, Ammiraju JS, Bhattarai KK, Mantelin S, Martinez de Ilarduya O, Roberts PA, et al. 2007. The $\mathrm{Mi}$-9 gene from Solanum arcanum conferring heat-stable resistance to root-knot nematodes is a homolog of $\mathrm{Mi}-1$. Plant Physiol. 143: 1044-1054.

Jacquet M, Bongiovanni M, Martinez M, Verschave P, Wajnberg E, Castagnone-Sereno P. 2005. Variation in resistance to the root-knot nematode Meloidogyne incognita in tomato genotypes bearing the Mi gene. Plant Pathol. 54: 93-99.

Jaubert S, Milac A, Petrescu A, De Almeida-Engler J, Abad P, Rosso M. 2005. In planta secretion of a calreticulin by migratory and sedentary stages of root-knot nematode. Mol. Plant Microbe Interact. 18: 1277-1284.

Jarquin-Barberena H, Dalmasso A, de Guiran G, Cardin M. 1991. Acquired virulence in the plant parasitic nematode Meloidogyne incognita. I. Biological analysis of the phenomenon. Rev. Nematol. 14: 261-275.

Javed N, Gowen SR, El-Hassan SA, Inam-Ul-Haq M, Shahina F, Pembroke B. 2008. Efficacy of neem (Azadirachta indica) formulations on biology of root-knot nematodes (Meloidogyne javanica) on tomato. Crop Prot. 27: 36-43. Javed N, Gowen SR, Inam-Ul-Haq M, Abdullah K, Shahina F. 2007. Systemic and persistent effect of neem (Azadirachta indica) formulations against root-knot nematodes, Meloidogyne javanica and their storage life. Crop Prot. 26: 911-916.

Jia Y, McAdams SA, Bryan GT, Hershey HP, Valent B. 2000. Direct interaction of resistance gene and avirulence gene products confers rice blast resistance. EMBO J. 19: 4004-4014.

Jones JD, Dangl JL. 2006. The plant immune system. Nature 444: 323-329.

Khallouk S, Voisin R, Van Ghelder C, Engler G, Amiri S, Esmenjaud D. 2011. Histological mechanisms of the resistance conferred by the Ma gene against Meloidogyne incognita in Prunus spp. Phytopathology 101: 945-951.

Kiewnick S, Dessimoz M, Franck L. 2009. Effects of the Mi-1 and the $N$ root-knot nematode-resistance gene on infection and reproduction of Meloidogyne enterolobii on tomato and pepper cultivars. J. Nematol. 41: 134-139.

Li H, Yang G, Shu H, Shu HR, Yang YT, Ye BX, et al. 2006. Colonization by the arbuscular mycorrhizal fungus Glomus versiforme induces a defense response against the root-knot nematode Meloidogyne incognita in grapevine (Vitis amurensis Rupr.), which includes transcriptional activation of the class III chitinase gene VCH3. Plant Cell Physiol. 47: 154-163.

Li X-Q, Wei J-Z, Tan A, Aroian RV. 2007. Resistance to root-knot nematode in tomato roots expressing a nematicidal Bacillus thuringiensis crystal protein. Plant Biotechnol. J. 5: 455-464.

Lozano-Torres JL, Wilbers RH, Gawronski P, Boshoven JC, Finkers-Tomczak A, Cordewener JH, et al. 2012. Dual disease resistance mediated by the immune receptor $\mathrm{Cf} 2$ in tomato requires a common virulence target of a fungus and a nematode. Proc. Natl. Acad. Sci. U.S.A. 109: 10119- 10124.

Maier TR, Hewezi T, Peng J, Baum TJ. 2013. Isolation of whole esophageal gland cells from plant-parasitic nematodes for transcriptome analyses and effector identification. Mol. Plant Microbe Interact. 13: 31-35. 
Melillo MT, Leonetti P, Bongiovanni M, Castagnone-Sereno P, Bleve-Zacheo T. 2006. Modulation of reactive oxygen species activities and $\mathrm{H}_{2} \mathrm{O}_{2}$ accumulation during compatible and incompatible tomato-root-knot nematode interactions. New Phytol. 170: 501-512.

Milligan SB, Bodeau J, Yaghoobi J, Kaloshian I, Zabel P, Williamson VM. 1998. The root-knot nematode resistance gene $M i$ from tomato is a member of the leucine zipper, nucleotide binding, leucine-rich repeat family of plant genes. Plant Cell 10: 1307-1319.

Mitreva-Dautova M, Roze E, Overmars H, de Graaff L, Schots A, Helder J, et al. 2006. A symbiont-independent endo-1,4- $\beta$-xylanase from the plant-parasitic nematode Meloidogyne incognita. Mol. Plant Microbe Interact. 19: 521-529.

Molinari S, Fanelli E, Leonetti P. 2014. Expression of tomato salicylic acid (SA)-responsive pathogenesis-related genes in Mi-1-mediated and SA-induced resistance to root-knot nematodes. Mol. Plant Pathol. 15: 255-264.

Molinari S. 2008. Salicylic acid as an elicitor of resistance to root knot nematodes in tomato. Acta Hortic. 789: 119-126.

Molinari S. 2009. Antioxidant enzymes in (a)virulent populations of root knot nematodes. Nematology 11: 703-711.

Molinari S and Miacola C. 1997. Interactions between resistant tomato cvs Meloidogyne spp. in vitro. Nematol. Medit. 25: 63-71.

Ogallo JL and McClure MA. 1996. Systemic acquired resistance and susceptibility to root-knot nematodes in tomato. Phytopathology 86: 498-501.

Opperman CH, Bird DM, Williamson DM, Rokhsar DS, Bruke M, et al. 2008. Sequence and genetic map of Meloidogyne hapla: a cpmpact nematode genome for plant parasitism. Proc. Natl. Acad. Sci. U.S.A. 105: 14802- 14807.

Pegard A, Brizzard G, Fazari A, Soucaze O, Abad P, Djian-Caporalino C. 2005. Histological characterization of resistance to different root-knot nematode species related to phenolics accumulation in Capsicum annuum. Phytopathology 95: 158-165.

Pieterse CMJ, Van Loon LC. 2007. Signalling Cascades Involved in Induced Resistance, in Induced Resistance for Plant Defence: A Sustainable Approach to Crop Protection (eds D. Walters, A. Newton and G. Lyon), Blackwell Publishing, Oxford, UK. doi: 10.1002/9780470995983.ch4.
Roberts PA and Thomason IJ. 1986. Variability in reproduction of isolates of Meloidogyne incognita and Meloidogyne javanica on resistant tomato genotypes. Plant Disease 70: 547-551.

Rosso M, Dubrana M, Cimbolini N, Jaubert S, Abad P. 2005. Application of RNA interference to root-knot nematode genes encoding esophageal gland proteins. Mol. Plant Microbe Interact. 18: 615-620.

Rooney HC, Van't Klooster JW, van der Hoorn RA, Joosten MH, Jones JD, de Wit PJ. 2005. Clasdosporium Avr2 inhibits tomato $\mathrm{Rcr} 3$ protease required for $\mathrm{Cf} 2$-dependent disease resistance. Science 308: 1783-1786.

Sahebani N and Hadavi N. 2009. Induction of $\mathrm{H}_{2} \mathrm{O}_{2}$ and related enzymes in tomato roots infected with root knot nematode (M. javanica) by several chemical and microbial elicitors. Biocontrol Sci. Techn. 19: 301-313.

Schaff JE, Nielsen DM, Smith CP, Scholl EH, Bird DM. 2007. Comprehensive transcriptome profiling in tomato reveals a role for glycosyltransferase in Mi-mediated nematode resistance. Plant Physiol. 144: 1079-1092.

Schumann GL, D'Arcy. 2010. Essential Plant Pathology. The American Phytopathological Society. St. Paul, Minnesota USA.

Seah S, Williamson VM, Garcia BE, Mejia L, Salus MS, Martin CT, et al. 2007. Evaluation of a co-dominant SCAR marker for detection of the Mi-1 locus for resistance to root-knot nematode in tomato germplasm. Rep. Tomato Genet. Coop. 57: 37-40.

Semblat JP, Rosso MN, Hussey RS, Abad P, CastagnoneSereno P. 2001. Molecular cloning of a cDNA encoding an emphid-secreted putative avirulence protein from the root-knot nematode Meloidogyne incognita. Mol. Plant Microbe Interact. 14: 72-79.

Shingles J, Lilley C, Atkinson H, Urwin P. 2007. Meloidogyne incognita: molecular and biochemical characterization of a cathepsin $\mathrm{L}$ cysteine proteinase and the effect on parasitism following RNAi. Exp. Parasitol. 115: 114-120.

Sikora RA, Fernandez E. 2005. Nematode parasites of vegetables, p. 319-392. In: M. Luc, RA. Sikora, JE. Bridge (eds.). Plant parasitic nematodes in subtropical and tropical agriculture. CABI Bioscience, Egham, UK.

Sobczak M, Avrova A, Jupowicz J, Phillips MS, Ernst K, Kumar A. 2005. Characterization of susceptibility and resistance responses to potato cyst nematode (Globodera 
spp.) infection of tomato lines in the absence and presence of the broad-spectrum nematode resistance Hero gene. Mol. Plant Microbe Interact. 18: 158-168.

Sorribas F, Ornat C, Verdejo-Lucas S, Galeano M, Valero J. 2005. Effectiveness and profitability of the Mi-resistant tomatoes to control root-knot nematodes. Eur. J. Plant Pathol. 111: 29-38.

Thies JA, Dickson DW, Fery RL. 2008. Stability of resistance to root-knot nematodes in 'Charlston Belle' an 'Carolina Wonder' bell pepper in a sub-tropical environment. HortScience 43: 188-190.

Triantaphyllou AC. 1987. Genetics of nematode parasitism on plants, p. 354-363. In: JA. Veech, DW. Dickson (eds.) Society of Nematologists, Inc., Hyattsville.

Tzortzakakis EA, Adam MaM, Blok VC, Paraskevopoulos C, Bourtzis K. 2005. Occurrence of Resistance-breaking Populations of Root-knot Nematodes on Tomato in Greece. Eur. J. Plant Pathol. 113: 101-105.

Ueda H, Yamaguchi Y, Sano H. 2006. Direct interaction between the Tobacco mosaic virus helicase domain and the ATP-bound resistance protein, $\mathrm{N}$ factor during the hypersensitive response in tobacco plants. Plant Mol. Biol. 61: 31-45.

Van der Biezen EA, Jones JDG. 1998. Plant disease-resistance proteins and the gene-for-gene concept. Trends Biochem. Sci. 23: 454-456.

Verdejo-Lucas S, Cortada L, Sorribas FJ, Ornat C. 2009. Selection of virulent isolates of Meloidogyne javanica by repeated cultivation of $\mathrm{Mi}$ resistance gene tomato rootstocks under field conditions. Plant Pathol. 58: 990-998.

Veremis JC, Roberts PA. 1996a. Differentiation of Meloidogyne incognita and $M$. arenaria novel resistance phenotypes in Lycopersicon peruvianum and derived bridge-lines. Theor. Appl. Genet. 93: 960-967.

Veremis JC, Roberts PA. 1996b. Relationship between Meloidogyne incognita resistance genes in Lycopersicon perivianum differentiated by heat sensitivity and nematode virulence. Theor. Appl. Genet. 93: 950-959.

Vos C, Claerhout S, Mkandawire R, Panis B, Waele D, Elsen A. 2012. Arbuscular mycorrhizal fungi reduce root-knot nematode penetration through altered root exudation of their host. Plant Soil 354: 335-345.

Vos P, Simons G, Jesse T, Wijbrandi J, Heinen L, Hogers R, et al. 1998. The tomato $M i-1$ gene confers resistance to both root-knot nematodes and potato aphids. Nature Biotechnol. 16: 1365-1369.

Wachira PM, Kimenju JW, Okoth SA, Mibey RK. 2009. Stimulation of nematode-destroying fungi by organic amendments applied in management of plant parasitic nematode. Asian J. Plant Sci. 8: 153-159.

Wang Y, Yang W, Zhang W, Han Q, Feng M, Shen H. 2013. Mapping of a heat-stable gene for resistance to southern root-knot nematode in Solanum lycopersicum. Plant Mol. Biol. Rep. 31: 352-362.

Weber E, Koebnik R. 2006. Positive selection of the Hrp pilin HrpE of the plant pathogen Xanthomonas. J. Bacteriol. 188: $1405-1410$

Weerasinghe R, Bird D, Allen N. 2005. Root-knot nematodes and bacterial Nod factors elicit common signal transduction events in Lotus japonicus. Proc. Natl. Acad. Sci. U.S.A. 102: 3147-3152.

Wieczorek K, Elashry A, Quentin M, Grundler FMW, Favery B, Seifert GJ, et al. 2014. A distinct role of pectate lyases in the formation of feeding structures induced by cyst and root-knot nematodes. Mol. Plant Microbe Interact. 27: 901-912.

Williamson V, Ho J, Wu F, Miller N, Kaloshian I. 1994. A PCR-based marker tightly linked to the nematode resistance gene, $\mathrm{Mi}$, in tomato. Theor. Appl. Genet. 87: 757-763.

Williamson VM, Roberts PA. 2009. Mechanisms and genetics of resistance, p. 301-325. In: RN. Perry, M. Moens, JL. Starr (eds.). Root-knot nematodes. CAB International, Wallingford, UK.

Yadav B, Veluthambi K, Subramaniam K. 2006. Host-generated double stranded RNA induces RNAi in plant-parasitic nematodes and protects the host from infection. Mol. Biochem. Parasit. 148: 219-222.

Yaghoobi J, Yates JL, Williamson VM. 2005. Fine mapping of the nematode resistance gene Mi-3 in Solanum peruvianum and construction of a $S$. lycopersicum DNA contig spanning the locus. Mol. Genet. Genomics 274: 60-69.

Yaghoobi J, Kaloshian I, Wen Y, Williamson VM. 1995. Mapping a nematode resistance locus in Lycopersicon peruvianum. Theor. Appl. Genet. 91: 457-464.

Yamaguchi Y, Pearce G, Ryan C. 2006. The cell surface leucine-rich repeat receptor for AtPep1, an endogenous peptide elicitor in Arabidopsis, is functional in transgenic 
tobacco cells. Proc. Natl. Acad. Sci. U.S.A. 103: 1010410109.

Yang S, Gu T, Pan C, Feng Z, Ding J, Hang Y, et al. 2008.
Genetic variation of NBS-LRR class resistance genes in rice lines. Theor. Appl. Genet. 116: 165-177. 